
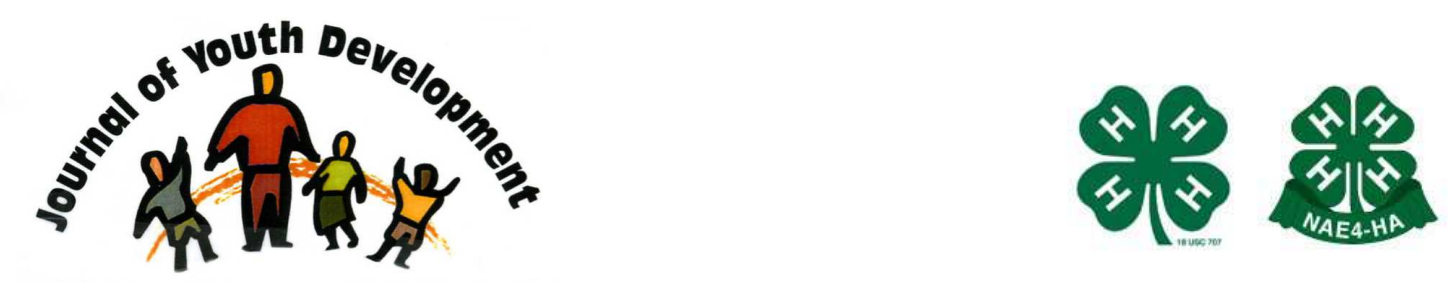

Bridging Research \& Practice

\title{
Helping Schools: Youth Development as a Form of Supplemental Education
}

\author{
Jan B. Carroll \\ 4-H Youth Development \\ Colorado State University \\ Jan.Carroll@colostate.edu \\ Jeff Goodwin \\ 4-H Youth Development \\ Colorado State University \\ Jeff.Goodwin@colostate.edu \\ Melissa Oliver \\ 4-H Youth Development \\ Colorado State University \\ Melissa.Oliver@colostate.edu
}




\section{JOURNAL OF YOUTH DEVELOPMENT \\ bridging research and practice

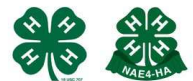

Bridging Research \& Practice

Volume 2, Number 1, Summer 2007

Article 0701FA005

\section{Helping Schools: Youth Development as a Form of Supplemental Education}

Jan B. Carroll, Jeff Goodwin and Melissa Oliver

Colorado State University

Abstract: This study measured the impact of 4-H Youth Development on Colorado's youth. Active youth were compared to those who did not participate in out-of-school activities. Data were collected from $5^{\text {th }}, 7^{\text {th }}$, and $9^{\text {th }}$ grade students. Results of the study confirm active students, including 4-H Youth Development members, were less likely to engage in at-risk behaviors. 4-H Youth Development can function as a form of supplemental education, contributing to academic, civic, and social success of young people.

\section{Introduction}

Youth development, including 4- $\mathrm{H}$, is one form of supplemental education - efforts by schools, parents, organizations and communities to enhance learning for K-12 students. According to Bridglall and Gordon (2002), "the idea of supplementary education is based on the assumption that high academic achievement is closely associated with exposure to family and communitybased activities and that occur outside of school in support of academic learning" (p. 1). They define supplemental education as "the formal and informal learning and developmental enrichment opportunities provided for students outside of school and beyond the regular school day or year" (p. 2).

Schools alone are unable to assure students opportunities to learn and practice all of the hard and soft skills required by today's workforce today. The basic skills required by U.S. businesses include traditional characteristics such as a positive attitude and a willingness to work hard, and also hard skills -- mathematics, problem solving and reading, and soft skills -- the ability to work in groups and present effectively both orally and in writing (Murnane \& Levy, 1996). These are not always taught during the regular school day, practiced in the classroom environment, measured on standardized tests, and/or reported to stakeholders as measures of school success. 
Youth development programs, including 4- $\mathrm{H}$, are:

well positioned to add value to the work of schools and families by building on young people's current knowledge and strengths. In addition, they can provide young people with the support, protection, guidance, and opportunities that will allow them all to take their places as the next generation of America's workers, family members, and citizens (Quinn, 1999, p. 113).

Other forms of supplemental education include after-school care and the many "educationrelated opportunities that ... parents make available to their children - for example travel, dance lessons, scouting, tutoring, summer camp, and so forth" (Gordon, Bridglall and Meroe, 2005, p. 40).

According to Ingles, et. al (2002), participation in extracurricular activities in eighth grade was one characteristic of students (others included exhibiting high math achievement, studying algebra, and attending private school) who were more likely to graduate from high school with a diploma and less likely to complete high school with a GED or to drop out. They also had higher postsecondary enrollment rates and bachelor's/higher degree attainment. These findings are important, since the income premium for having a bachelor's degree over having no postsecondary education was about 33 percent in 2002.

Furthermore, educational attainment is associated with all seven attributes of democratic citizenship - that is, more active and effective citizenship, as shown by the 1990 Citizen Participation Study (Nie, Junn, \& Stehlik-Barry, 1996).

Although 4-H Youth Development has celebrated 100 years in Colorado and has extensive reach and potential for promoting positive youth development, little systematic analysis of effectiveness has been conducted in the state, nor indeed among any youth development organizations (Quinn, 1999).

The purpose of this study was to measure the impact that the 4-H Youth Development experience has had on Colorado's young people. As state and county budgets become tighter and tighter, the 4-H Youth Development program must demonstrate its effectiveness with sound data to enhance the rich anecdotal information more easily available. Research-based information is critical to future 4-H Youth Development programs.

Also examined were students who were active in out-of-school-time activities other than 4- $\mathrm{H}$ and their involvement in at-risk behaviors. This paper focuses on these data and relates the findings to the value of 4-H Youth Development as a form of supplemental education.

\section{Methods and Procedures}

This Colorado 4-H Impact Study was undertaken to determine the impact 4-H Youth Development may have had on students in Colorado public schools. Colorado State University's Human Research Committee (HRC) gave approval to survey Colorado $5^{\text {th }}, 7^{\text {th }}$ and $9^{\text {th }}$ grade students.

There were 1906 useable surveys returned. The data were entered, coded and analyzed as a capstone project by the spring 2005 BK 410 Marketing Research class in the College of Business 
at Colorado State University. Some data were reviewed by the university's Department of Statistics for data entry accuracy and additional data analysis.

\section{Population}

The population for the Colorado 4-H Impact Study consisted of a stratified random sample of 15 counties in Colorado. A stratified random sample was used to insure an equal distribution of counties among the three Extension regions in the state (North, South, and West). In each county, four schools were randomly selected. The list of schools was retrieved from the Colorado Educational Directory 2004 - 2005 (Colorado Department of Education, 2005). Using the complete list of schools that had $5^{\text {th }}, 7^{\text {th }}$ and/or $9^{\text {th }}$ grades, a computer random generator was used to determine the selected schools. These grades were selected because they represent the audience served by 4-H Youth Development (Goodwin et al. 2005).

Before the administration of the survey, some selected counties and some schools within selected counties determined they would not be able participate. Alternate counties and schools had been selected and did participate.

\section{Development of Instruments}

The survey instrument used to assess the ways young people spent their time out of school and how that use of time may affect their academic, emotional, social and cognitive development was modeled on a study conducted in 2000 by the Montana Extension Service (in collaboration with researchers at Montana State University), and replicated in Idaho in 2002 - 2003. The Search Institute approved the use of some of their survey questions for the Montana survey; subsequently, Idaho and Colorado requested and were granted permission to carry those questions forward for their replication studies.

The original instrument consisted of principally high quality (valid and reliable) questions taken from other national or state surveys (Astroth \& Haynes, 2002). It included questions of basic demographic and family-oriented content as well as questions categorized into seven subscales:

- Positive self-identity

- Social competency

- Relationships with adults

- Self confidence

- Empowerment

- Kindheartedness

- Skills

To save students' time during administration of the survey, Colorado's edition included only 65 questions. Redundant items were eliminated in consultation with the BK410 Marketing Research students whose early group assignment included shortening the survey.

The survey was divided into seven sections (see Table 1). The question formats included fill-inthe-blank, yes/no, essay, circle those that apply (Likert-type scale), and multiple-choice. A Spanish version of the survey was available for those students who had difficulty reading or comprehending English. No Spanish-language surveys were returned. 
Table 1

Design of the survey

\begin{tabular}{|c|c|l|}
\hline Section & Questions & \multicolumn{1}{c|}{ Purpose } \\
\hline 1 & $1-2$ & $\begin{array}{l}\text { Gather extracurricular activity and negative behavior information about } \\
\text { the subjects of the study }\end{array}$ \\
\hline 2 & $3-9$ & $\begin{array}{l}\text { Determine the way the students perceived themselves regarding their } \\
\text { personal identity }\end{array}$ \\
\hline 3 & $10-15$ & Have the participants assess their levels of social competency \\
\hline 4 & $16-27$ & $\begin{array}{l}\text { Same as above } \\
\text { Measure specifically how the individuals felt concerning their self } \\
\text { confidence, character and personal empowerment }\end{array}$ \\
\hline 5 & $28-38$ & $\begin{array}{l}\text { Determine whether the students cared about others, life skills they have } \\
\text { learned and demographics, including age, grade, gender, location of } \\
\text { family living unit, grades in school, and family composition }\end{array}$ \\
\hline 7 & $54-65$ & $\begin{array}{l}\text { Ascertain whether participants had been, or currently were, a 4-H Youth } \\
\text { Development member. } \\
\text { Those who had no experience completed the survey at this point. } \\
\text { - Students who had experience with 4-H Youth Development were } \\
\text { asked to complete the rest of section seven, which was designed } \\
\text { to measure the impact of 4-H Youth Development on those } \\
\text { students who had participated. }\end{array}$ \\
\hline
\end{tabular}

\section{Collection of Data}

The survey instruments were delivered to or picked up by the local Cooperative Extension agent in each participating county. Packets of instructions on how to administer the survey were sent to all county Extension agents in the selected counties. They made initial contacts with the school superintendents and/or principals. Letters of cooperation were secured from each participating school in every selected county.

Surveys were implemented within the randomly selected schools in those counties after HRC approval was granted. Parental "opt out" letters of informed consent were sent previous to the actual administration of the survey. Administration of the questionnaires was conducted in the spring of 2005. A follow-up was not necessary as all students completed the surveys during the class period.

Surveys were not coded in advance. However, when each class finished within the participating grade, the surveys were wrapped with an accompanying tracking sheet filled in with pertinent information by the county Extension agent or other facilitator. Surveys were sent to the State 4-H Office where they were checked in and distributed to those BK410 class members whose assignment was data entry. SPSS was the program used for data entry and analysis. Response rates are reported in Table 2. 
Table 2

Response to the survey instrument

\begin{tabular}{|l|r|}
\hline Respondent Groups & \multicolumn{1}{|c|}{ Frequency } \\
\hline Counties & 15 \\
\hline Students & 2003 \\
\hline
\end{tabular}

\section{Coding and Analysis of Data}

The BK410 Marketing Research class at Colorado State University coded and entered the data into SPSS and each of five small groups from the two sections prepared a report and presentation for the State 4-H Office. Four of the groups reported frequencies only. For the SPSS program to analyze the dependent variables, the fifth group converted the rankings of the Likert-type scales to numerical classes and treated them as interval level variables:

$$
\begin{aligned}
& 1=\text { Strongly Agree } \\
& 2=\text { Agree } \\
& 3=\text { Neutral } \\
& 4=\text { Disagree } \\
& 5=\text { Strongly Disagree }
\end{aligned}
$$

Missing data were coded as $9=$ "missing" for electronic entry after they were received. These were deleted from statistical analysis. Ninety-seven questionnaires were unusable due to incorrect completion, wrong grade surveyed for information, and/or empty spaces. Analyses were conducted with 1,906 usable returned surveys.

The fifth small group from BK410 conducted and reported statistical analysis of the data. Logistic regression using the chi-square $\left(\mathrm{X}^{2}\right)$ test was performed for analysis. The statistics laboratory in the Colorado State University Department of Statistics reviewed the data entry for accuracy, and provided additional data analysis.

\section{Frequencies and percentages}

Frequencies and percentages were complied on the questions regarding extracurricular participation, negative behaviors, positive identity, social competency, contact with adults, self confidence, empowerment, caring about others, skills learned, age, grade, gender, household size, location of family living unit, family types, and impact of 4-H Youth Development on members.

\section{Findings and Discussion}

\section{Participants}

Respondents were asked to indicate a number of background characteristics to contribute to the statistical analysis. Of the 1906 respondents who participated in the survey,

- 49.9 percent were male, and 49.2 percent were female.

- 393 reported they had been involved in the 4-H Youth Development program for at least one year.

Of those 406 respondents who had ever been in 4-H Youth Development, 294 of them had been a member for two years or more. 
The age range reported was between 10 and 15 with outliers at ages 9,16 , and 17 . Students were asked to specify which grade they were in at the time of the survey: $5^{\text {th }}, 7^{\text {th }}$, or $9^{\text {th }}$. Of the participants,

- 41.7 percent identified themselves as being in the $5^{\text {th }}$ grade;

- 37.6 percent reported to be in the 7th grade; and

- 20.7 percent said they were in the 9th grade.

Concerning location of residence, of the 1,906 total respondents,

- sixty-one respondents did not indicate where they were living;

- 12.9 percent lived on a farm;

- 24.8 percent lived in the country, but not on a farm; and

- 62.2 percent lived in town.

Of the $4024-\mathrm{H}$ Youth Development respondents to this question,

- 31.1 percent lived on a farm;

- 27.4 percent lived in the country but not on a farm; and

- 41.5 percent lived in town.

\section{Active and Non-Active Students}

Analysis of the data revealed that Colorado youth in the sample who were involved in out-ofschool activities were less likely to be involved in a variety of at-risk behaviors when compared to youth who were not involved in any out-of-school activities (Table 3). This was congruent with data from the Montana study, where "youth who are involved in out-of-school activities were found to be less likely to be involved in a whole range of at-risk behaviors when compared to youth who are not involved in any out-of-school activities" (Astroth and Haynes, 2002, pp. 34).

To determine the involvement in the identified at-risk behaviors, respondents answered yes or no to this wording on the survey instrument, "During the past year did you.....

- Cheat on a test?

- Drink any alcohol without parental permission?

- Shoplift?

- Use any drugs like marijuana, methamphetamines, or cocaine; or sniff glue or other fumes to get high?

- Smoke cigarettes?"

Table 3 shows that there was a highly significant statistical difference between active and nonactive respondents in all identified at-risk behaviors except "cheated on a test." The incidence of cheating on tests increased with grade level. When all grades $\left(5^{\text {th }}, 7^{\text {th }}\right.$, and $\left.9^{\text {th }}\right)$ were examined (Table 3 ) the incidence of cheating on a test was reported at 23.7 percent for active students and 25.7 percent for non-active students. There was no statistical difference between the groups of students. When the $9^{\text {th }}$ grade respondents were examined separately, however (Table 4), incidences were reported at the higher levels of 43.9 percent for active students and 37.5 percent for non-active students. There was still no statistical difference between the groups. 
Table 3

Percent of Students (all grades) Involved in At-Risk Behaviors

\begin{tabular}{|c|c|c|c|c|}
\hline Variable & \multicolumn{2}{|c|}{ Active Students } & \multicolumn{2}{|c|}{ Non-Active Students } \\
\hline & Percent & \# & Percent & \# \\
\hline Cheated on a test & 23.7 & (385 of 1624) & 25.7 & (64 of 249) \\
\hline Drank alcohol & $15.1^{* *}$ & (244 of 1619 ) & 23.1 & (58 of 251) \\
\hline Shoplifted & $5.5^{* *}$ & (89 of 1613 ) & 12.5 & (31 of 248) \\
\hline Used drugs & $6.6^{* *}$ & (107 of 1614 ) & 13.2 & (33 of 251) \\
\hline Damaged property & $11.9 * *$ & (193 of 1618$)$ & 19.9 & (50 of 251) \\
\hline Smoked & $7.8^{* *}$ & (126 of 1613 ) & 14.4 & (36 of 250$)$ \\
\hline
\end{tabular}

Respondents in the $9^{\text {th }}$ grade who did not participate in any out-of-school activities reported that they were more likely to shoplift, use drugs, damage property, and smoke cigarettes. In fact, the non-active students were more than twice as likely to shoplift and more than twice as likely to use drugs (Table 4). Montana data showed non-active $9^{\text {th }}$ graders to be twice as likely to shoplift, and nearly three times as likely to use drugs (Astroth and Haynes, 2002).

Table 4

Percentage of Active and Non-Active 9th Grade Students Engaged in At-risk Behaviors

\begin{tabular}{|c|c|c|c|c|}
\hline \multirow[t]{2}{*}{ Variable } & \multicolumn{2}{|c|}{ Active Students } & \multicolumn{2}{|c|}{ Non-Active Students } \\
\hline & Percent & \# & Percent & \# \\
\hline Cheated on a test & 43.9 & (143 of 326$)$ & 37.5 & (24 of 64$)$ \\
\hline Drank alcohol & 39.3 & $(128$ of 326$)$ & 43.8 & (28 of 64$)$ \\
\hline Shoplifted & $8.3^{*}$ & (27 of 326 ) & 18.8 & (12 of 64$)$ \\
\hline Used drugs & $12.9 * *$ & (42 of 325$)$ & 29.7 & (19 of 64$)$ \\
\hline Damaged property & $17.2^{*}$ & (56 of 326$)$ & 28.1 & (18 of 64$)$ \\
\hline Smoked & $17.8^{* *}$ & (58 of 326$)$ & 34.4 & (22 of 64$)$ \\
\hline
\end{tabular}

Considering this difference between the active and non-active students, researchers asked if there were any difference between the $9^{\text {th }}$ grade 4-H Youth Development members and the other active $9^{\text {th }}$ grade students in their responses to the at-risk behavior questions. The results are shown on Table 5. Ninth grade 4-H Youth Development members were again significantly less likely to use drugs than were the active students who had never belonged to 4-H Youth Development (Table 5), but data did not indicate they were less likely to participate in other at-risk behaviors. 
Table 5

9th Grade 4-H Youth Development Students and Non-4-H Youth Development Active 9th Grade Students Engaged in At-risk Behaviors

\begin{tabular}{|c|c|c|c|c|}
\hline \multirow[t]{2}{*}{ Variable } & \multicolumn{2}{|c|}{$\begin{array}{l}\text { 4-H Youth Development } \\
9^{\text {th }} \text { Grade Students }\end{array}$} & \multicolumn{2}{|c|}{$\begin{array}{c}\text { Non-4-H Youth Development } \\
\text { But Active } \\
9^{\text {th }} \text { Grade Students }\end{array}$} \\
\hline & Percent & $\#$ & Percent & \# \\
\hline Cheated on a test & 44.9 & (35 of 78$)$ & 42.7 & $(103$ of 241$)$ \\
\hline Drank alcohol & 39.7 & (31 of 78$)$ & 38.2 & (92 of 241) \\
\hline Shoplifted & 9.0 & (7 of 78$)$ & 7.5 & (18 of 241$)$ \\
\hline Used drugs & $6.4^{*}$ & (5 of 78$)$ & 15.0 & (36 of 240$)$ \\
\hline Damaged property & 16.7 & (13 of 78$)$ & 17.0 & (41 of 241$)$ \\
\hline Smoked & 12.8 & $(10$ of 78$)$ & 19.1 & (46 of 241$)$ \\
\hline
\end{tabular}

Reported academic performance of active and non-active students is summarized below (Table 6). Students who were active in out-of-school activities were more likely to report getting better grades than those students who were not active in such programs. Almost 65 percent of the active students reported they had received either mostly A's or about half A's and half B's. In contrast, only about 40 percent of those students who were non-active reported they had received mostly A's or about half A's and half B's. Bridglall and Gordon (2002) agree that those high achieving students who have experienced supplementary education efforts "identify with high achievement values" and "have good study skills and other learner behaviors" (p. 2).

Table 6

Academic Performance of Active and Non-Active Students (all grades)

\begin{tabular}{|c|c|c|c|c|}
\hline Grades & \multicolumn{2}{|c|}{ Active Students** } & \multicolumn{2}{|c|}{ Non-Active Students } \\
\hline & Percent & \# & Percent & \# \\
\hline Mostly A's & 31.1 & (504 of 1623) & 11.6 & (29 of 250$)$ \\
\hline$A^{\prime} s$ and $B^{\prime} s$ & 33.7 & (547 of 1623 ) & 29.6 & (74 of 250$)$ \\
\hline Mostly B's & 6.0 & (97 of 1623 ) & 6.4 & $(16$ of 250$)$ \\
\hline B's and C's & 16.2 & (263 of 1623$)$ & 23.2 & (58 of 250$)$ \\
\hline Mostly C's & 2.8 & (46 of 1623 ) & 5.2 & (13 of 250$)$ \\
\hline C's and D's & 6.8 & (111 of 1623$)$ & 14.4 & (36 of 250 \\
\hline Mostly D's & 1.6 & (26 of 1623$)$ & 4.4 & (11 of 250$)$ \\
\hline Less than D's & 1.8 & (29 of 1623 ) & 5.2 & (13 of 250$)$ \\
\hline
\end{tabular}

\section{Discussion and Recommendations}

Researchers expected to find 4-H Youth Development participants indicating they were less involved in at-risk behaviors and more involved in asset-building behaviors. While the latter was reflected in the data reported elsewhere, the difference in at-risk behaviors was actually between active and non-active youth, where 4-H may or may not have been one of the activities. 
Youth development programs staff increasingly recognize "the need to work in meaningful partnerships with other community institutions especially schools" (Quinn, p. 112). Inserting 4-H Youth Development curriculum and activities into programs and sites already serving youth (such as Boys and Girls Clubs, YMCA and YWCA, Girls, Inc., the National Urban League, schoolbased after school programs, faith-based youth groups, etc.) is one way to partner. Afterschool programs are, in fact, among the most widespread forms of supplementary education (Bridglall and Gordon, 2002). 4-H Cooperative Curriculum System (4-HCCS) materials

(http://www.n4hccs.org/) are jury reviewed and available for use in all counties, states, and territories. Colorado's Seasonal 4-H Clubs model

(http://www.4h.colostate.edu/schoolenrichment/schoolenrichment.shtml) is another design that can come off the shelf and into the supplemental education environment with minimal preparation. While intended for out-of-school use, these materials are aligned with Model Content Standards for Learning and with Bridglall's and Gordon's (2002) targeted supplemental education strategy to "nurture academic achievement as instrumental to personal and political agency" (p. 3).

Framing 4-H Youth Development programs as a form of supplemental education provides the opportunity to position a traditional program within a modern effort to provide youth with the skills they need for today's workforce and society.

\section{References}

Astroth, K. A. \& Haynes, G. W. (2002). More than cows \& camp; cooking: Newest research shows the impact of 4-H youth development. Journal of Extension [On-line], 40. Available at: http://www.joe.org/joe/2002august/a6.shtml.

Colorado Department of Education (2004). Colorado Education and Library Directory. Denver, CO: Colorado Department of Education. [On-line]. Available at http://www.cde.state.co.us/edulibdir/.

Bridglall, B. L. \& Gorden E. W. (March 2002). The idea of supplementary education. Pedagogical Inquiry and Praxis (3).

Goodwin, J., Barnett, C., Pike, M., Peutz, J., Lanting, R., \& Ward, A. (2005). Idaho 4-H impact study. Journal of Extension [On-line], 43 Article a4. Available at:

http://www.joe.org/joe/2005august/a4.shtml.

Gordon, E. W., Bridglall, B. L., \& Meroe, A. S. (2005). Supplementary Education: The Hidden Curriculum of High Academic Achievement. Lanham, MD: Rowman \& Littlefield.

Ingles, S. J., Thomas, R., Curtin, P. K., Alt, M. N. \& Chen, X. (2002). Coming of Age in the 1990's: The Eighth-Grade Class of 198812 Years Later. [On-line]. Available at http://nces.ed.gov/prograns/quarterly/vol 4/4 2/2-1asp 
Murnane, R. J. \& Levy, F. (1996). Teaching the New Basic Skills. New York: The Free Press.

Nie, N.H., Junn, J., \& Stehlik-Barry, K. (1996). Education and Democratic Citizenship in America. Chicago: University of Chicago Press.

Quinn, J. (1999). Where need meets opportunity: Youth development programs for early teens. The Future of children When School is Out, 9 (2), $96-116$.

(C) Copyright of Journal of Youth Development Bridging Research and Practice. Content may not be copied or emailed to multiple sites or posted to a listserv without copyright holder's express written permission. However, users may print, download or email articles for individual use. 